\title{
Molecular Investigation of Diversity Normal Yeast Flora in Cow Raw Milk Industrial Farms of Tehran Province and Alborz
}

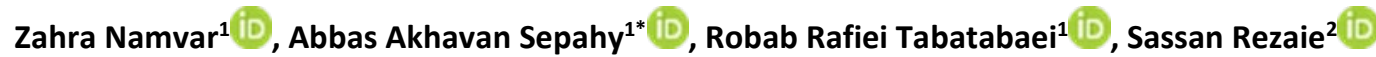

1. Department of Microbiology, School of Biological Sciences, Islamic Azad University, North Tehran Branch, Tehran, Iran

2. Depatment of Medical Mycology and Parasitology, Division of Molecular Biology, School of Public Health, Tehran University of Medical Sciences, Tehran, Iran

10.30699/ijmm.15.3.317

\section{ABSTRACT}

Background and Aim: Milk is a completely rich and complex environment suitable for different microorganisms including bacteria and Fungi. The majority of studies were conducted on milk-bacterial flora and aflatoxin-contaminations in dairy products; however, despite the importance of yeasts in usage as starter in the dairy industries and their effect on the taste of dairy products as well as in dairy probiotic characteristics, almost no information exist concerning fungal-flora in milk. So, the aim of this study was investigation on the raw milk yeast-microflora and it's relation to the hygienic level and other characteristics of dairy farms. Existence of fungus were studied in defined raw milk samples and the diversity of isolated yeasts were examined.

Materials and Methods: Samples were collected within a period of one year (March 2016-March 2017) and evaluated based on Internal Transcribed Spacer (ITS-1-ITS-2) parts of rDNA. Isolated yeasts were identified using PCR-RFLP and Sequencing tests.

Results: Total of 262 raw milk samples were collected from 14 farms in Tehran and Alborz provinces in Iran. About $66 \%$ of milk samples contained yeast microflora. The dominant isolated yeasts were characterized as: Candida globose, Geotrichum candidum, Pichia kudriavzevii, Tricosporon asahii, Pichia jadinii, Kluyveromyces marxianus, Magnusiomyces capitatus, Wickeihameilla pararugosa, and Candida inconspicua. Other candida species such as Candida parapsilosis, Candida tropicalis, and Candida glabrata were also isolated in a limited level.

Conclusion: Dominant yeast flora was identified in raw cow's milk samples. The obtained results also indicated that fungal diversity varies from field to field. However, similarities in some isolated species have been revealed.

Keywords: Milk, Micro-flora, PCR-RFLP, Sequencing, Yeast Received: 2020/12/17; Accepted: 2021/04/25; Published Online: 2021/06/28

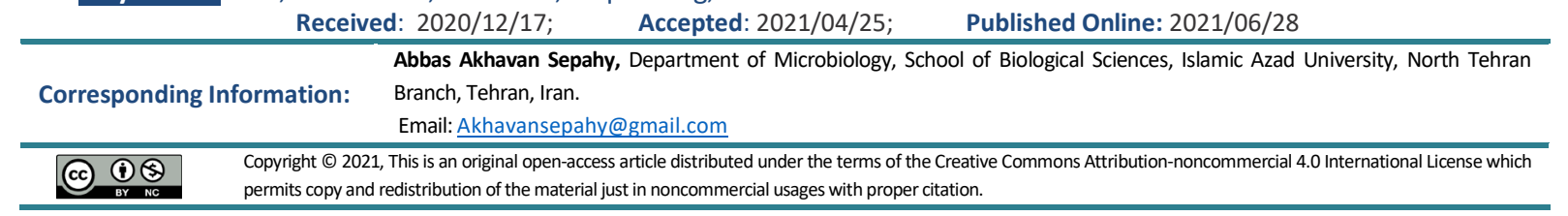

Use your device to scan and read the article online

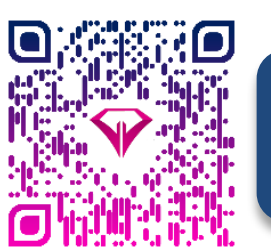

Namvar Z, Akhavan Sepahy A, Rafiei Tabatabaei R, Rezaie S,. Molecular Investigation of Diversity Normal Yeast Flora in Cow Raw Milk Industrial Farms of Tehran Province and Alborz. Iran J Med Microbiol. 2021; 15 (3) 315-324

Download citation: BibTeX | RIS | EndNote | Medlars | ProCite | Reference Manager | RefWorks
Send citation to:
8 Mendeley
2 zotero
E) RefWorks

\section{Introduction}

The World Food Organization (FAO) and its 191 member states have introduced June $1^{\text {st }}$ as the World Milk Day since 2001, in line with its commitment to protect the public access to adequate and high-quality food for healthy living. The organization has urged all governmental and non-governmental organizations to 
inform people of the milk importance as the most comprehensive and indispensable food for all groups on this day (1).

Milk as a complete food source contains nutrients, minerals and vitamins needed by the body and as one of the most important products of the agricultural sector, it is of great importance. About $85 \%$ of human milk is consumed from cow's milk (1).

Milk is a complete meal for human consumption and its health condition is very effective in human health. Since milk is a rich and complex environment of various nutritional compounds; it can also be useful for other microorganisms, including fungi and bacteria. This nutrient can be contain various compounds including proteins, carbohydrates, fats, vitamins and minerals (2).

Since raw milk is used in the various dairy industries, including yogurt, cheese, dough, etc., the composition of the microbial flora is remarkable. Although most attention has been paid to bacterial flora, but also fungal flora, since some yeast can be used as a starter in the dairy industry, or as a probiotic, it is important to examine them, and it can be helpful to identify and raise the level of health of the milk to raise the level of public health (3).

Determining the primary quality of the fungal flora of the milk can be identified by identifying secondary contamination that occurs during transportation and in environmental conditions. In order to investigate these factors, we made the necessary precision at all stages, including livestock hygiene, tank health, and hygiene devices. Yeast and molds can also be an important microbial population in raw milk that is affected by the conditions of animal, physiology, the weather, season and nutrition (3).

Milk can be a source of different non-starter fungi, although microflora of different dairy industries such as dough, yogurt, and cheese has been investigated, but identification of the primary source can be better for us (4). In a 2010 study in China, 11 yeast species were identified in milk (5). Few studies have been done on the cow's milk variety. Identification of the yeast used in the cheese industry as a starter is helpful as it is also effective in the flavor and taste of the cheese (4).

But until this study, the presence of fungal flora in Iranian milk has not been reported. Most research is on milk samples contaminated with mycotoxins.

The results of this study determined the fungal flora of milk in the samples and can be used in somatic studies of tuberculosis to identify related animal diseases such as mastitis in herds. Also, the reported type of yeast can affect the price of milk, which is directly related to its quality in factories, and can be classified based on the amount of fungal flora reported.

The purpose of this study was identification and molecular characterization of the fungal-microflora in raw cow's milk. This study focused on illustrating the diversity of yeast species in cow's raw milk from industrial farms of Tehran province and Alborz, Iran.

\section{Materials and Methods}

\section{Selection of Farms}

In this Cross-sectional study, random farms were selected from Tehran and Alborz provinces, Iran. The samples were collected from 14 farms and examined during March 2016 to March 2017. Milk samples were collected by random sampling every month from the milk collection tanks and transferred by sterile Falcon tubes $\left(0-4^{\circ} \mathrm{C}\right)$ to the laboratory. Tanks containing milk for more than $1 \mathrm{~h}$ were excluded from the study. Samples were collected immediately after sterilization of the last livestock in the farm in a sterile Falcon tube. It did not reach the time of one hour and so on. This study was sampled in four seasons as shown below.

\section{Isolation of Yeast Flora}

First, the samples were cultured for preparation. Milk samples were cultured on Yeast Extract Agar (YEA) with antibiotics (penicillin \& streptomycin 1\%) and incubated at $35^{\circ} \mathrm{C}$ for $48-48 \mathrm{~h}$. Then grown-up colonies were stained by the lactophenol cotton blue (LCB) for yeast shape. Evolution and were passaged on Sabourate Dexterose Agar (SDA) with antibiotics and placed at $35^{\circ} \mathrm{C}$ for $48-48$ hours.

\section{Diagnosis of Yeasts using CHROM Agar Medium}

Some types of yeasts are specifically identified by creating colored colonies on the chromogenic agar medium. Accordingly, we incubated yeasts on this medium at $30^{\circ} \mathrm{C}$ for 48 hours and then examined them.

\section{Identification of Yeast Species using RFLP-PCR:}

Yeast DNA extraction was performed according to a procedure previously described by using phenolchloroform technique (6). DNA concentration and purity were determined by Nanodrop (Thermoscientifics, USA).

\section{PCR analysis}

To amplify the internal spacer region ITS1-5.8S-ITS2 of the yeast rDNA genes, two universal primers, ITS1: 5"TCCGTAGGTGAACCTGCGG3" and ITS-4: 5"TCCTCCGCTTATGATATGC3" were used (7). PCR analysis of genomic DNA was performed according to the standard protocol using synthetic oligonucleotide primers. Briefly, $2.5 \mu \mathrm{L}$ of each primer (OD 20, 10 pmol) was added to a volume of $45 \mu \mathrm{L}$ containing: $10 \mathrm{X}$ 
PCR buffer $+\mathrm{MgCl}_{2}, 10 \mathrm{mM}$ dNTP mix, 1 unit/ $\mu \mathrm{L}$ of Taq DNA polymerase and template (genomic DNA) (Amplicon, Denmark). Thermal cycle reaction was carried out by a thermal cycler (Peqlab. Germany). It was composed of a pre-denaturation at $94^{\circ} \mathrm{C}$ for 5 minutes followed by 35 cycles of denaturation at $94^{\circ} \mathrm{C}$ for 30 seconds, annealing at $58^{\circ} \mathrm{C}$ for 45 seconds, and a final extension step at $72^{\circ} \mathrm{C}$ for 75 seconds. PCR products were analyzed by electrophoresis through a 1\% agarose under ultraviolet Trans illumination.

\section{RFLP}

The MSPI (Hpall) enzyme was used to digest PCR products (7). Briefly, $10 \mu \mathrm{L}$ of PCR product, $1.5 \mu \mathrm{L}$ of enzyme, $3 \mu \mathrm{L}$ Tongue buffers, and $18 \mu \mathrm{L}$ nuclease -free water were mixed and the mixture was incubated for 1.5 hours at $37 \circ \mathrm{C}$. Restricted fragments were then revealed by electrophoresis through a $2 \%$ agarose and the obtained results were analyzed by compare with previously reported data.

\section{PCR Product Sequencing:}

The PCR fragments from yeast samples which could not be identified by RFLP method, was forwarded for a sequence analysis. The obtained results were then investigated for identifying in BLAST (NCBI, NIH)

\section{Statistical Analysis}

Excel 2016 software (Microsoft, USA) was used for data analysis. The data was entered into Excel and sor- ted by collection time. The average number of total yeasts during different seasons was calculated using Excel software and its standard deviation was determined.

\section{Results}

\section{Identification of Yeast:}

In this study, 262 milk samples were collected from 14 farms. The number of samples collected in Spring, Summer Autumn, and Winter were 55, 79, 74 and 54, respectively. The microbial analysis of milk samples were performed with a focus on normal yeast flora in milk. The total number of isolates for each genus and species from farms was included in Table 1 . The yeast samples studied microscopically and then cultured on Chrom-agar medium; the obtained results were analyzed based on the pigments produced and shown in Figure 1.

We did our research in four seasons, and the frequency and type of yeast were shown in Figures 2$\underline{5}$. Among the seasons, the highest levels of yeast were found in the Autumn (Figure 6).Mean and standard deviation number of yeasts by different seasons were shown in Figure7. The most striking feature of this chart is that based on the somatic cell count, which is generally considered to be a measure of microbial load of milk, and is more commonly used for cows' mastitis, as we can see, the number of infected samples were more in Spring.

Table 1. Isolated yeast from milk samples.

\begin{tabular}{|c|c|c|c|c|}
\hline Genus & Total & Species & Total & $\begin{array}{c}\text { Number of } \\
\text { farms }\end{array}$ \\
\hline \multirow{7}{*}{ Candida } & \multirow{7}{*}{72} & glabra & 2 & 1 \\
\hline & & globosa & 33 & 9 \\
\hline & & inconspicua & 16 & 8 \\
\hline & & tropicalis & 6 & 4 \\
\hline & & Parapsilosis & 10 & 7 \\
\hline & & Utilis & 1 & 1 \\
\hline & & pesudoglobosa. & 3 & 3 \\
\hline \multirow{2}{*}{ Galactomyces } & \multirow{2}{*}{4} & Candidum & 3 & 3 \\
\hline & & Geotrichum & 2 & 1 \\
\hline Geotrichum & 12 & candidum & 12 & 6 \\
\hline Kluyveromyces & 64 & marxianus & 64 & 12 \\
\hline Cryptococcus & 1 & amylolentus & 1 & 1 \\
\hline \multirow{2}{*}{ Cutaneotrichosporon } & \multirow{2}{*}{11} & curvatus & 10 & 4 \\
\hline & & Smithiae & 1 & 1 \\
\hline Magnusiomyces & 15 & capitatus & 15 & 8 \\
\hline \multirow{3}{*}{ Pichia } & \multirow{3}{*}{90} & jadinii & 19 & 9 \\
\hline & & Cactophila & 3 & 1 \\
\hline & & Fermentans & 10 & 5 \\
\hline
\end{tabular}


320 Molecular Investigation of Diversity Normal Yeast Flora...

\begin{tabular}{|c|c|c|c|c|}
\hline Genus & Total & Species & Total & $\begin{array}{c}\text { Number of } \\
\text { farms }\end{array}$ \\
\hline & & Kudriavzevii & 57 & 12 \\
\hline & & Heedi & 1 & 1 \\
\hline saprochaete & 3 & clavata & 3 & 2 \\
\hline sporopachydermia & 1 & lactativora & 1 & 1 \\
\hline \multirow{3}{*}{ Tricosporon } & \multirow{3}{*}{31} & asahii & 24 & 10 \\
\hline & & Montovideence & 6 & 5 \\
\hline & & Lactis & 1 & 1 \\
\hline Trapelia & 1 & elacista & 1 & 1 \\
\hline \multirow{2}{*}{ Wickeihameilla } & \multirow{2}{*}{15} & pararugosa & 14 & 9 \\
\hline & & Sorbophila & 1 & 1 \\
\hline Rhodotoroula & 1 & millaginosa & 1 & 1 \\
\hline Meyerozyma & 1 & guilliermondi & 1 & 1 \\
\hline
\end{tabular}

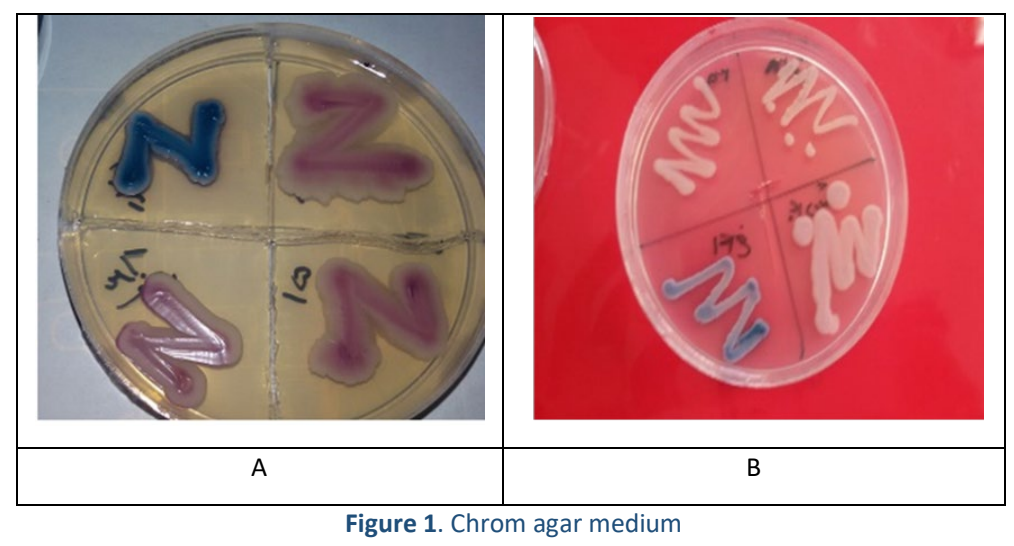

According to the pigments produced, using Chrom agar medium culture, the color of the fungus colony has been determined. Figure A shows the fungus

Candida tropicalis and image B shows the fungus Candida Krusei

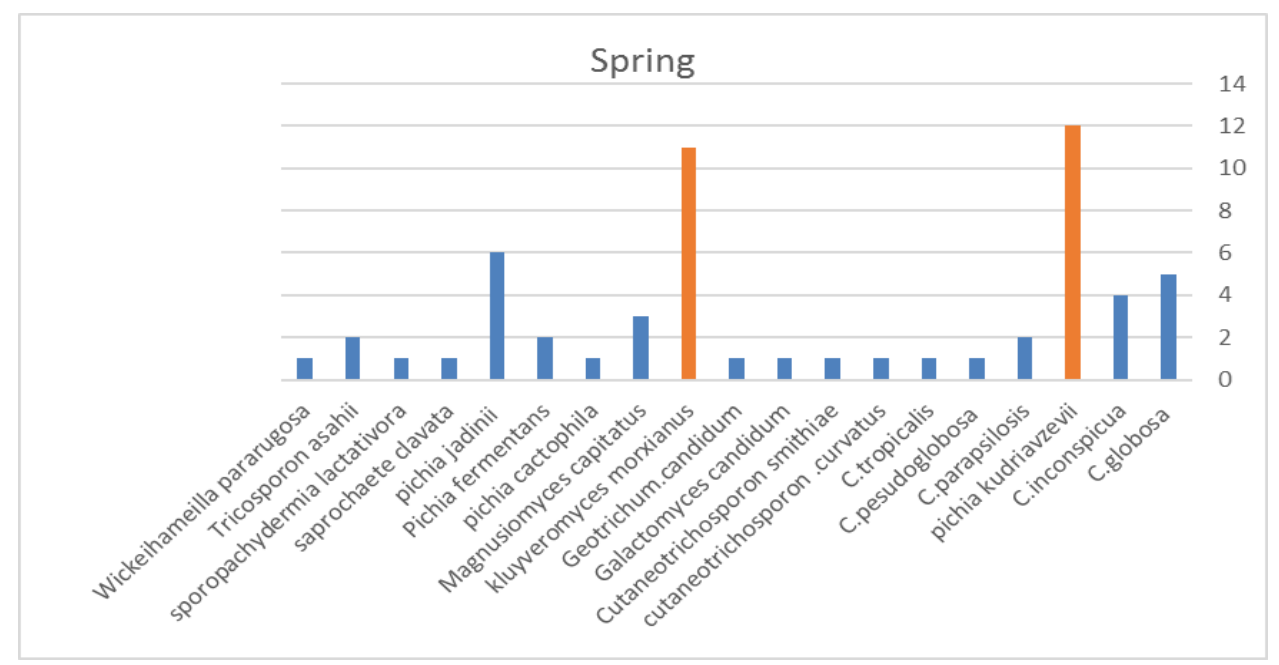

Figure 2. In this season, the levels of Kluyveromyces marxianus and Pichia kudriavzevii are almost the same. 


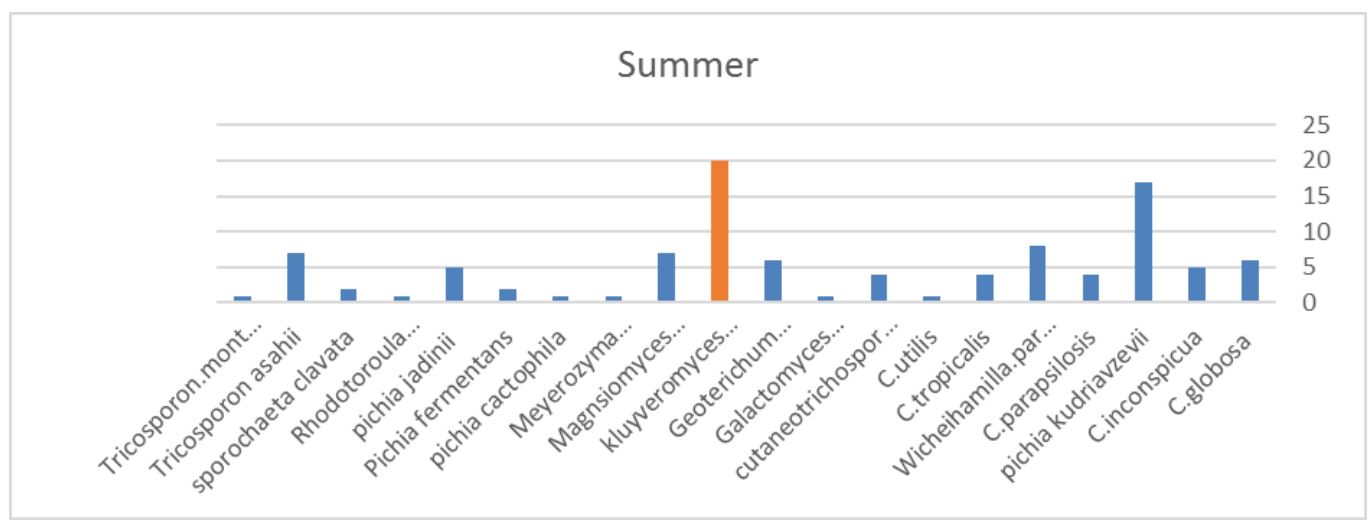

Figure 3. In this season, Kluyveromyces marxianus is more than the others.

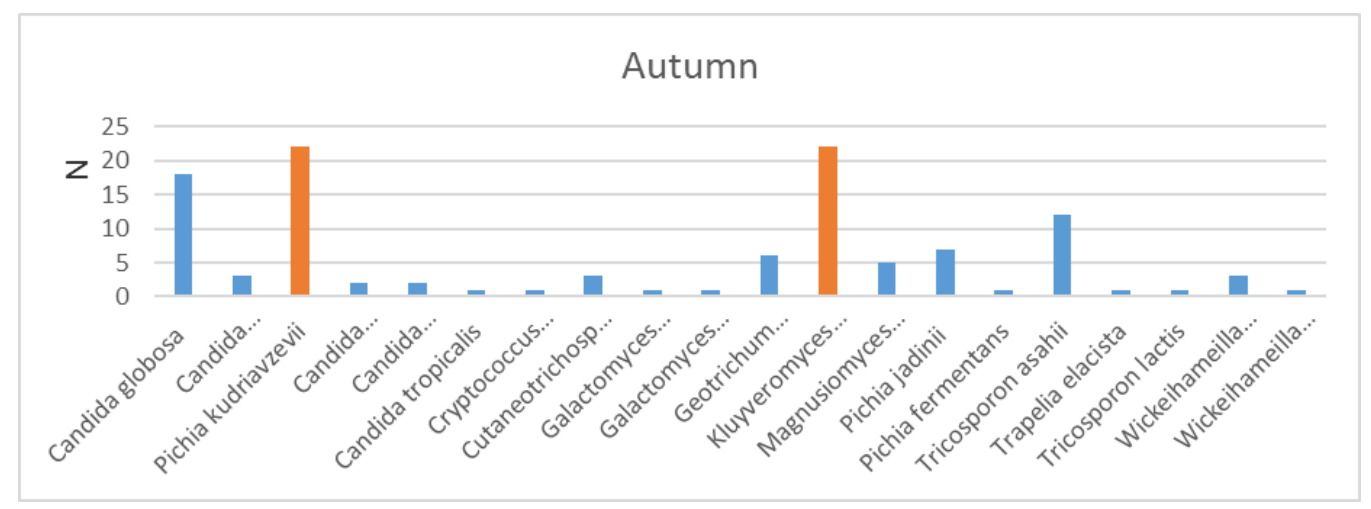

Figure 4. In this season, Kluyveromyces marxianus and Pichia kudriavzevii are the same and more than others.

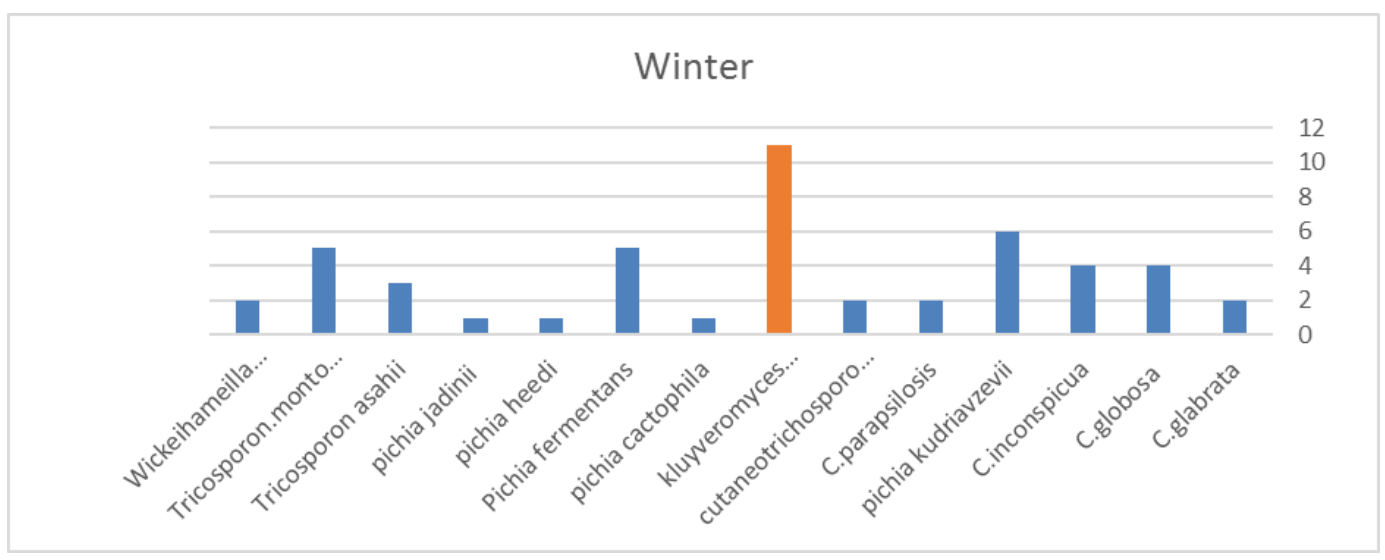

Figure 5. In this season, Kluyveromyces marxianus is more than the others

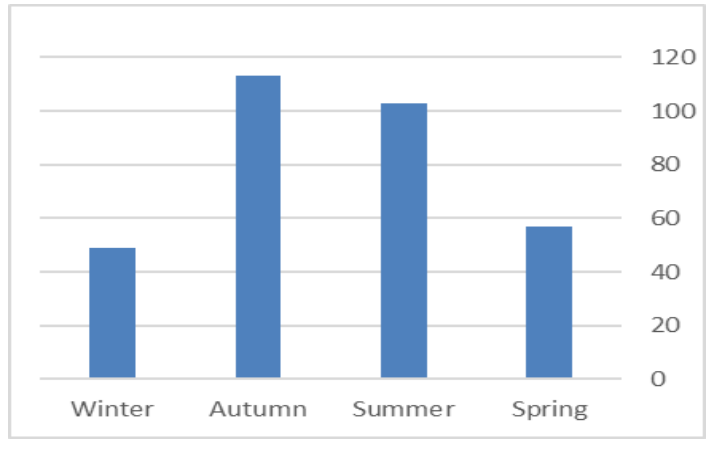

Figure 6. The yeast in different seasons

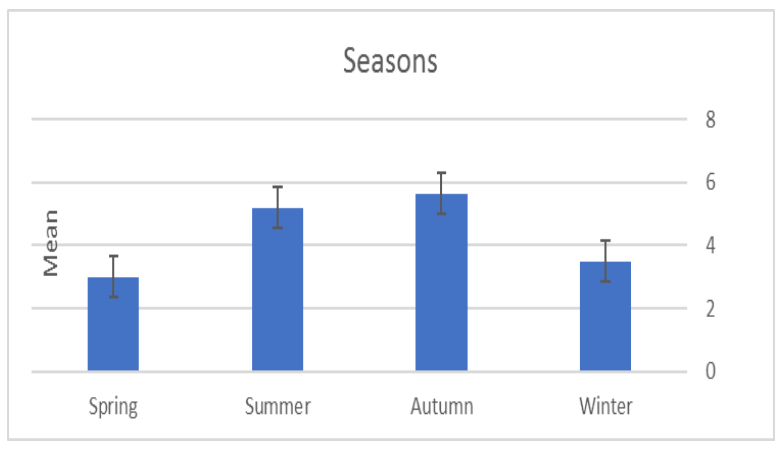

Figure 7. Mean (and standard deviation) number of yeasts by different seasons 


\section{Molecular Identification of Yeast:}

Using the PCR-RFLP method based on the length of the digested parts, the yeasts were identified. The results were indicated in Figures 8 and $\underline{9}$.

\section{Sequencing}

Identifying all yeasts method was not possible by PCR-RFLP. Therefore, the nucleotide sequencing method was used to obtain the exact result based on the results obtained and compared with the gene bank.

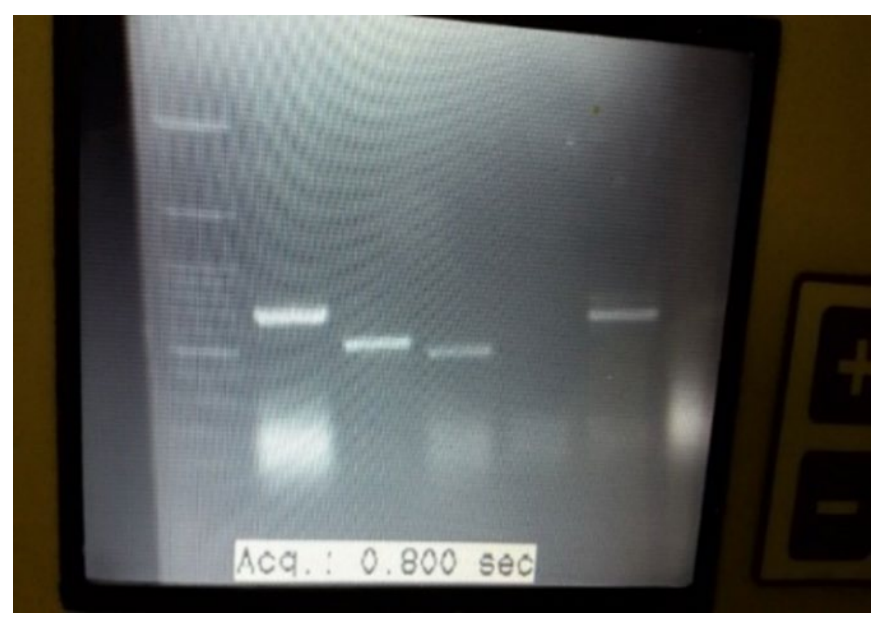

Figure 8. PCR product of Candida Spp.: The length of size marker bands (Lane1) are: 2000-1500-1000-900-800-700-600-500-400-300-200100 bp (from top of bottom), Lane2-6 are Candida spp.

\section{Discussion}

Milk health is important as a source of food and precursor fermentation product. The interest in drinking raw milk of cattle is growing in some societies, and many people believe that it is important to consume it for their health. Raw milk is a perfect food, however, it can be microbiologically hazardous for consumers. Food is needed for life, but this role can be overshadowed due to the fact that they sometimes cause illness instead of an effect on growth. All foods can be contaminated physically, chemically, and biologically. Milk contributes to both food sources and consumer health (8).

In Europe, raw milk is sold directly in some countries, such as Germany, France, the Netherlands, Belgium, Denmark, Italy, and Ireland (9).

Milk has been found to be a good food source for many types of microorganisms due to its diverse nutrient ingredients that support microorganisms (3). It is also a good source for some probiotics such as Saccharomyces cerevisiae (10).

Yeast play an important role in the fermentation of dairy industries due to lipolytic and proteolytic activity and atopic dermatitis with raw milk in the early years of life (3). Some yeasts produce pathogenic microorganisms and inhibit the production of inhibitors (11)

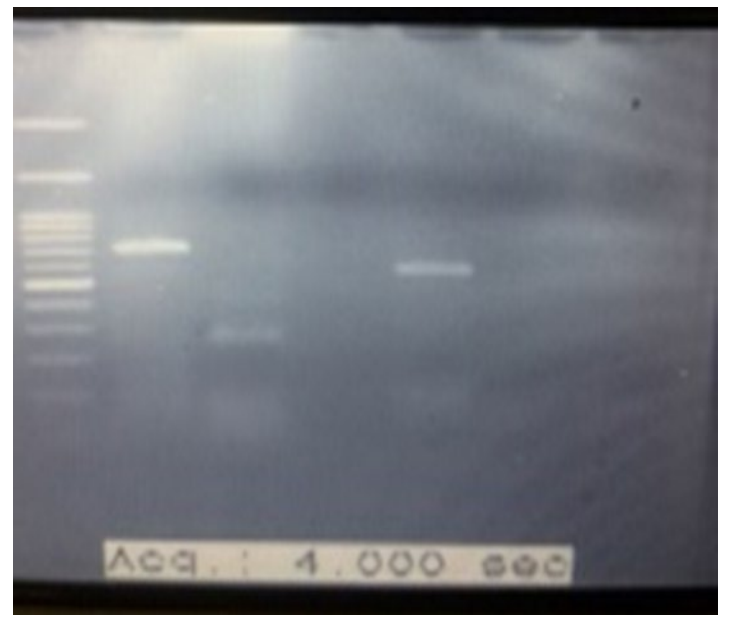

Figure 9. Digestion of PCR Product with MSPI: The length of size marker bands (Lane1) are: 2000-1500-1000-900-800-700-600-500400-300-200-100bp (from top of bottom), Lane2: kluyveromyces marxianus Lane3: Candida tropicalis Lane5: Candida parapsilisis
Understanding the microorganisms of Eukaryote in addition to increasing the knowledge of their classification is important because identification of fungi have been considered in terms of the production of aflatoxin and its effects on human health $(9,12,13)$. Also, yeasts can be a cause for mastitis in cattle (9). Also, due to the type of microorganisms present in the milk, the taste and flavor of the products derived from milk will be different (14). Therefore, their identification is very critical and important.

Yeasts such as Candida, Saccharomyces, and Kuyveromyses have been observed in milk. Yeasts are the main components of the microbiota of fermented milks. In some dairy products, yeasts use lactic acid, which leads to a decrease in $\mathrm{pH}$, which promotes the secondary growth of $\mathrm{pH}$-sensitive microbiota. The growth of bacteria is also triggered by amino acids and vitamins produced from yeasts. Yeasts display a variety of metabolic capabilities, such as proteolytic and lipolytic activity, that can play a significant role in taste and aroma (11).

In 2008, Karmen Godič Torkar in Sloan checked the quality of the milk and reported the presence of yeast and molds with $95 \%$ yeast and $51.5 \%$ Geoterichum, while our percentage of yeast and Geoterichum contained $81.3 \%$ and $3 / 7 \%$, respectively. Their exam- 
ination was done only in the winter and summer, but our review was done in four consecutive seasons (15).

Karine Lavoie et al. studied on fungi flora of raw milk and cheese in 2012, which was similar to our research in terms of Candida, Cryptococcus, Galactomyces, Pichia, Rhodotorula, and Tricosporon kluyveromyces detection (4). In a study in China in 2010, conducted by Chen et al., 11 species of yeasts were identified. Information on the fungal diversity of raw milk is low (5). In 2013, in Italy, Simona Panelli et al. studied the variation of fungal microflora in raw milk at Alpine altitudes, based on the height of the grasslands, using srRNA 26, its, and the beta-tubulin gene. Their study showed that increase in height of the grasslands is related with increase of fungal diversity. Yeast dominant microorganism and Kluyveromyces marxianus was the most abundant (12) which was similar to results of the present study. In the same year, in other areas of Italy, cheese products were also studied, and yeasts were identified (16). Mostly, research has been done on milk products such as cheese and raw milk. In 2013, Nataša Golić, discovered yeasts in the study of soft fresh cheese in Serbia, which included Kuyveromyces, Debaromyces, Saccharomyces, Candida, and Torulospora (17). In 2014, Marie-Christine Montel et al. studied on cheese products of raw milk in France. They found mold and yeast (18).

In the 2015 survey on milk products in fermented dairy products in Russia, it was shown that the Ascomists, Basidimists, Chytridiomycota and Pichia yeasts are dominant (19).

The same yeasts have been studied in dairy products from around the world in different papers $(11,20,24)$. Based on the variation of milk flora, there is little information of yeasts available compared to bacteria or even aflatoxin producing species. However, the level of health of this fungal survey is very important, especially in cheese-making dairy industry. We used molecular RFLP and sequencing methods in this study. In researches performed on milk, yeasts such as Candida, Rhodotorula, Geotrichum, Kluyveromyces, Terichosporon, Cryptococcus are usually reported (3). The results we found were consistent with the findings of the study of Karine Lavoie in Canada on 2012. In this study, $67 \%$ of the yeasts were identified, and there were many common species (4). Our results were also consistent with the French survey, though not the one cinducted in Canada (18). But it was not similar to the results revealed in the investigation by $\mathrm{H}$. Ksontini et al. in Tunisia (2).

In our study, 15 genera and 31 species were found, most of which were related to Kluyveromyces marxianus and then Pichia kudriavzeii, and then Candida globosa. Note that this is important to us because kluyveromyces is very important for the dairy industry, such as kefir production, and Pichia kudriavzeii, as a pathogen in human beings. Our results were similar to the 2012 study conducted in Quebec, perhaps due to the common breed of the Holstein. There was a variety of species regarding Candida and $C$. globosa was the second most prevalent species, but in our research, it was the third most common cause (4).

Also, the flora diversity of each farm was seen unlike the 2006 and 2009 studies that reported the same (25).

Also, our results were similar to those in France. The study, which was conducted in 2011, found Candida, Geotrichum, Cryptococcus, Kluyveromyces, Pichia.Rodoturola, and Trichosporonspecies. Of course, Geotrichum, Candida, Kluyveromyces were dominant (26).

We saw more fungal diversity in the Autumn, but it was higher in February in Winter in their study. In their research they also found Yarrowia lipolytica (26).

In many cases, where microflora and milk microbiology have been studied, most of the bacterial species have been noted, and in the case of fungi, the presence of yeast has been reported (2).

Identification of yeasts is important in both pathogenesis and biotechnology. For example, yeasts such as Yarrowia lipolytica is a manufacturer-supplied host for a wide variety of biotechnology applications that are commonly found in some foods and dairy products, such as protein sources for livestock foods, for the production of organic acids or hydrophobic substrates, unsaturated long chain fatty acids and carotenoids (27). But in our study, this yeast was not detected.

Some yeasts such as the ones that can be found in cheese, do not disappear after pasteurization. Since the yeasts $C$. tropicalis, C. krusei, C. papsilosis, and $C$. glabrata are pathogenic in humans and animals, and even Trichosporon asahii is pathogenic in immunecompromised individuals, it is important to identify the natural flora of milk. Finally, it is clear that compliance with health standards is important for consumers. In addition to consumers, it is also important for dairy producers to follow protocols as these same factors can cause mastitis in livestock, which reduces milk supply and increases the cost of keeping and treating livestock.

\section{Conclusion}

Understanding the microbial community of the milk helps to identify the environmentally compatible cases as well as its infectious agents, and factors affecting the taste and smell of the dairy products. It also helps to choose more suitable starter to make the flavor more favorable. 


\section{Acknowledgment}

We would like to thank our colleagues at the Medical Mycology Laboratory, School of Public Health, Tehran University of Medical Sciences, Tehran, Iran.

\section{Reference}

1. Górska-Warsewicz H, Rejman K, Laskowski W, Czeczotko M. Milk and dairy products and their nutritional contribution to the average polish diet. Nutrients. 2019 Aug;11(8):1771. [PMID] [PMCID]

2. Ksontini H, Kachouri F, Hamdi M. Microflora distribution and assessment of microbiological quality milk from Tunisian collection centres. Afric J Microbiol Res. 2011;5(12):1484-91. [DOI:10.5897/AJMR10.887]

3. Quigley L, O'sullivan O, Stanton C, Beresford TP, Ross RP, Fitzgerald GF, et al. The complex microbiota of raw milk. FEMS Microbiol Rev. 2013;37(5):664-98. [DOI:10.1111/1574-6976.12030] [PMID]

4. Lavoie K, Touchette M, St-Gelais D, Labrie S. Characterization of the fungal microflora in raw milk and specialty cheeses of the province of Quebec. Dairy Sci Technol. 2012;92(5):455-68. [DOI:10.1007/s13594-011-0051-4] [PMID] [PMCID]

5. CHEN LS, Ma Y, MAUBOIS JL, CHEN LJ, LIU QH, GUO JP. Identifcation of yeasts from raw milk and selection for some specific antioxidant properties. Int J Dairy Technol. 2010;63(1):47-54. [DOI:10.1111/j.1471-0307.2009.00548.x]

6. Xiao W. Yeast protocols: Springer; 2006. [DOI:10.1385/1592599583] [PMID]

7. Mohammadi R, Mirhendi H, Rezaei-Matehkolaei A, Ghahri M, Shidfar MR, Jalalizand N, et al. Molecular identification and distribution profile of Candida species isolated from Iranian patients. Med Mycol. 2013;51(6):657-63.

\section{[DOI:10.3109/13693786.2013.770603] [PMID]}

8. Sepahvand $R$, Bahmani $M$, Ahmadi-Roozbahani $H$, Hatamikia M, Tavasoli M, Rajabi T, et al. Microbial quality assessment of pasteurized milk of supplied to Loerstan province market, Southwest of Iran. J Chem Pharm Sci.

9. Zastempowska E, Grajewski J, Twarużek M. Foodborne pathogens and contaminants in raw milk-a review. Annals Animal Sci. 2016;16(3):623-39. [DOI:10.1515/aoas-2015-0089]

10. Fakruddin $M$, Hossain $M N$, Ahmed MM. Antimicrobial and antioxidant activities of Saccharomyces cerevisiae IFST062013, a potential probiotic. BMC Complement Altern Med.

\section{Conflict of Interest}

The authors reported no conflict of interest.

\section{7;17(1):64. [DOI:10.1186/s12906-017-1591-9] [PMID] [PMCID]}

11. Mu Z, Yang X, Yuan H. Detection and identification of wild yeast in Koumiss. Food Microbiol. 2012;31(2):301-8. [DOI:10.1016/j.fm.2012.04.004] [PMID]

12. Panelli S, Brambati E, Bonacina C, Feligini M. Diversity of fungal flora in raw milk from the Italian Alps in relation to pasture altitude. SpringerPlus. 2013;2(1):405. [DOI:10.1186/2193-1801-2-405] [PMID] [PMCID]

13. Hedayati MT, Omran SM, Soleymani A, Armaki MT. Aflatoxins in food products in Iran: A review of the literature. Jundishapur J Microbiol. 2016;9(7). [DOI:10.5812/jjm.33235]

14. Larpin-Laborde S, Imran $M$, Bonaïti C, Bora N, Gelsomino R, Goerges S, et al. Surface microbial consortia from Livarot, a French smear-ripened cheese. Canad J Microbiol. 2011;57(8):651-60. [DOI:10.1139/w11-050] [PMID]

15. Torkar KG, Teger SG. The microbiological quality of raw milk after introducing the two day's milk collecting system. Acta Agricult Slovenica. 2008;92(1):61-74.

16. Neviani E, Bottari B, Lazzi C, Gatti M. New developments in the study of the microbiota of rawmilk, long-ripened cheeses by molecular methods: the case of Grana Padano and Parmigiano Reggiano. Front Microbiol. 2013;4:36. [DOI:10.3389/fmicb.2013.00036] [PMID] [PMCID]

17. Golić N, Čadež N, Terzić-Vidojević A, Šuranská H, Beganović J, Lozo J, et al. Evaluation of lactic acid bacteria and yeast diversity in traditional white pickled and fresh soft cheeses from the mountain regions of Serbia and lowland regions of Croatia. Int J Food Microbiol. 2013;166(2):294-300. [DOI:10.1016/i.ijfoodmicro.2013.05.032] [PMID]

18. Montel M-C, Buchin S, Mallet A, Delbes-Paus C, Vuitton DA, Desmasures N, et al. Traditional cheeses: rich and diverse microbiota with associated benefits. Int J Food Microbiol. 2014;177:136-54. [DOI:10.1016/j.ijfoodmicro.2014.02.019] [PMID] 
19. Liu W, Zheng Y, Kwok L-Y, Sun Z, Zhang J, Guo Z, et al. High-throughput sequencing for the detection of the bacterial and fungal diversity in Mongolian naturally fermented cow's milk in Russia. BMC Microbiol. 2015;15(1):45. [DOI:10.1186/s12866-015-0385-9] [PMID] [PMCID]

20. Alegría Á, Szczesny P, Mayo B, Bardowski J, Kowalczyk M. Biodiversity in Traditional Polish Cheese Oscypek Determined by Culture-dependent and-independent Approaches. Appl Environ Microbiol. 2012:AEM. 06081-11. [DOI:10.1128/AEM.06081-11] [PMID] [PMCID]

21. Ghiamati F, Yavarmanesh $M$, Khomeiri $M$, Maghsoudlou $Y$. Biodiversity and origin of the microbial populations isolated from Masske, a traditional Iranian dairy product made from fermented Ewe's milk. International J Dairy Technol. 2016;69(3):441-51. [DOI:10.1111/1471-0307.12281]

22. Garofalo C, Osimani A, Milanović V, Aquilanti L, De Filippis F, Stellato $G$, et al. Bacteria and yeast microbiota in milk kefir grains from different Italian regions. Food Microbiol. 2015;49:123-33. [DOI:10.1016/j.fm.2015.01.017] [PMID]

23. Hosseini H, Hippe B, Denner E, Kollegger E, Haslberger A. Isolation, identification and monitoring of contaminant bacteria in Iranian Kefir type drink by $16 \mathrm{~S}$ rDNA sequencing. Food Control. 2012;25(2):784-8.

[DOI:10.1016/j.foodcont.2011.12.017]

24. Spanamberg A, Wunder Jr E, Brayer Pereira DI, Argenta J, Cavallini Sanches EM, Valente P, et al. Diversity of yeasts from bovine mastitis in Southern Brazil. Revista Iberoamericana Micol. 2008;25(3):154. [DOI:10.1016/S11301406(08)70036-6]

25. El-Sharoud W, Belloch C, Peris D, Querol A. Molecular identification of yeasts associated with traditional Egyptian dairy products. J Food Sci. 2009;74(7):M341-M6. [DOI:10.1111/i.17503841.2009.01258.x] [PMID]

26. Delavenne E, Mounier J, Asmani K, Jany J-L, Barbier G, Le Blay G. Fungal diversity in cow, goat and ewe milk. Int J Food Microbiol. 2011;151(2):247-51. [DOI:10.1016/i.ijfoodmicro.2011.08.029] [PMID]

27. Groenewald M, Boekhout T, Neuvéglise C, Gaillardin C, Van Dijck PW, Wyss M. Yarrowia lipolytica: safety assessment of an oleaginous yeast with a great industrial potential. Critic Rev Microbiol. 2014;40(3):187-206. [DOI:10.3109/1040841X.2013.770386] [PMID] 


\title{
مجله ميكروبشناسى يزشكى ايران

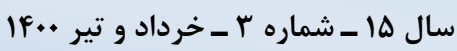 \\ Journal homepage: www.ijmm.ir
}

مقاله

\section{بررسى مولكولى تنوع فلور نرمال مخمرى در مزارع صنعتى شير خام كاو استان تهران و البرز}

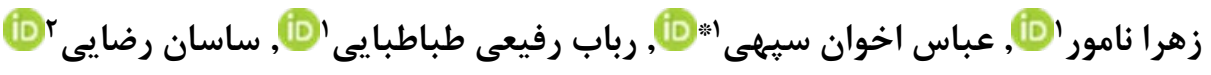

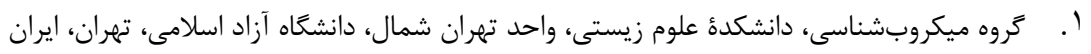

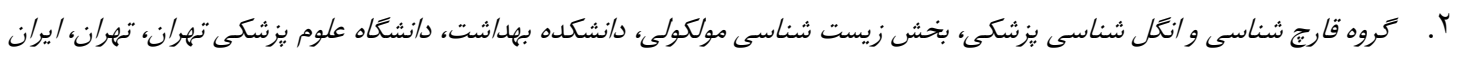

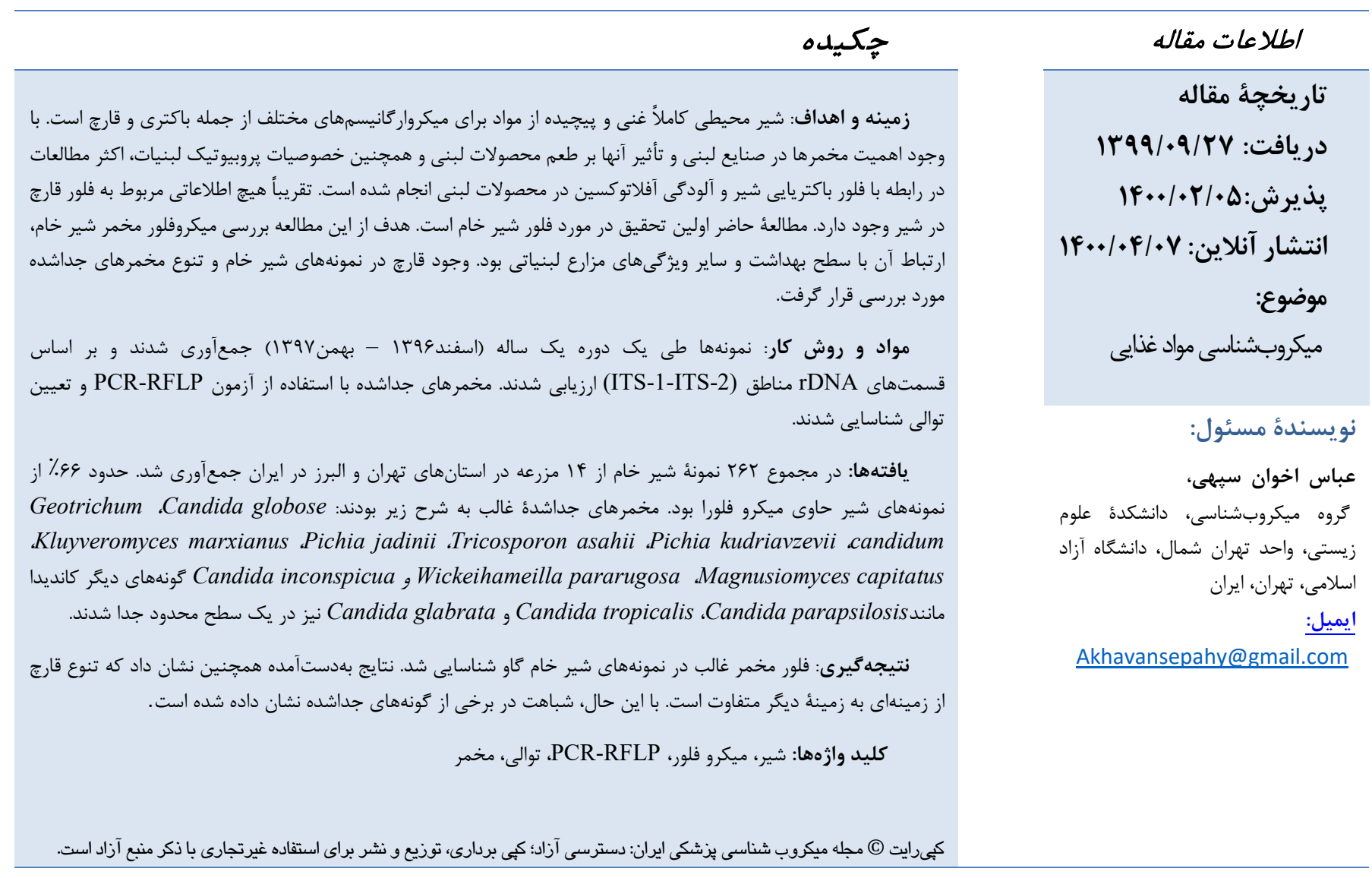

